\title{
Thermal tolerance of Stypocaulon scoparium (Phaeophyta, Sphacelariales) from eastern and western shores of the North Atlantic Ocean
}

\author{
I. Novaczek, A. M. Breeman* \& C. van den Hoek \\ Department of Marine Biology, Biological Centre, P.O. Box 14, NL-9750 AA, Haren (Gn), \\ The Netherlands
}

\begin{abstract}
Isolates of Stypocaulon scoparium Kütz. were collected from the Gulf of St. Lawrence, Canada and compared in culture to isolates collected from the Atlantic and Mediterranean coasts of Europe. The Canadian isolates grew at temperatures ranging from $-2{ }^{\circ} \mathrm{C}$ up to $22^{\circ} \mathrm{C}$, with maximum rates of growth at $10-15^{\circ} \mathrm{C}$; in trials lasting 3 months they survived the lowest temperatures but died at 22 or $25^{\circ} \mathrm{C}$. In contrast, for the European isolates, maximum growth occurred between 10 and $27^{\circ} \mathrm{C}$, and they died only after several months at 30 or $33^{\circ} \mathrm{C}$. At the low end of the temperature range, European plants suffered damage or died at $5^{\circ} \mathrm{C}$. Only the northernmost isolate, from Brittany, could both survive at $0^{\circ} \mathrm{C}$ and remain undamaged at $5^{\circ} \mathrm{C}$ in short days. All European isolates died at $-2{ }^{\circ} \mathrm{C}$. Geographic distributions and the different thermal responses suggest that the eastern and western Atlantic populations are two different entities, the European plants being possibly of Tethyan origin, and the Canadian plants being possibly of north Pacific origin. The former would then have occupied the north Atlantic for the longest time, which may partly explain the occurrence of ecotypic variation among these isolates.
\end{abstract}

\section{INTRODUCTION}

By considering the temperature regime at the geographic limits of a species, one can often predict the temperature limits for survival, growth or reproduction that keep a species within its geographic boundaries (van den Hoek, 1982a, b; Breeman, 1988). At times, however, one finds an anomalous pattern of distribution for which no workable hypothesis of limiting conditions is evident. Such is the case for the amphi-Atlantic brown alga known as Stypocaulon scoparium Kütz. or Halopteris scoparia (L.) Sauvageau.

In Europe, Stypocaulon scoparium is found in the outer Baltic Sea (Waern, 1952), the Black and Caspian Seas (Zinova, 1967), the Mediterranean and Red Seas (Menez \& Mathieson, 1981), in West Agder in southern Norway (Rueness, 1977), along western Denmark (Christensen et al., 1985), around England, Ireland and all but the northeast of Scotland (Maggs, 1986) and from northern France south to Morocco and the Cape Verde Islands (Audiffred, 1985) or perhaps to Nigeria.(Lawson \& John, 1982). At its northernmost limit of distribution on the Norwegian coast it experiences an average temperature fluctuation of about $6-14^{\circ} \mathrm{C}$, and in the Baltic of about $2-16^{\circ} \mathrm{C}$. At the southern limit in the southern Mediterranean and Red Seas, temperatures range from about 18 to $28^{\circ} \mathrm{C}$, while in Nigeria temperatures range from about $24-28^{\circ} \mathrm{C}$.

* Addressee for reprints 
On the coast of North America, the species is confined to a relatively narrow range between northern Labrador and southern Nova Scotia in Canada (South \& Tittley, 1986). Temperature ranges at the northern and southern limits are -2 to $10^{\circ} \mathrm{C}$ and 0 to $18^{\circ} \mathrm{C}$, respectively. There has been a single unsupported record from eastern Greenland (Kjellman, 1883).

In the North Atlantic Ocean, geographic limits of species are commonly set by low winter or low summer temperatures to the north, and high winter or high summer temperatures to the south (Breeman, 1988). Stypocaulon scoparium in the southern Mediterranean and south along the coast of Africa to Nigeria must tolerate several months of summer temperatures exceeding $25^{\circ} \mathrm{C}$. At the southern limit of distribution on the North American coast, winter temperatures are relatively low and therefore, presumably not limiting, and summer temperatures do not exceed $20^{\circ} \mathrm{C}$. One would expect the species to extend much farther south on the coast of North America, at least to North Carolina (where extensive sandy shores may form a barrier), but this is not the case. On the other hand, in winter, plants growing in the Gulf of St. Lawrence in Canada clearly tolerate months of sub-zero temperatures under a cover of ice. Why, then, do the European plants not extend much farther north along the relatively temperate coasts of Norway and southern Iceland where temperatures in both summer and winter are warmer than or equal to temperatures at the northern limit of distribution in eastern Canada?

To answer the questions posed by the distributions of Stypocaulon scoparium on the eastern and western sides of the North Atlantic, we have brought into culture isolates from both Canadian and European shores to study their thermal responses under controlled conditions.

\section{MATERIALS AND METHODS}

Stypocaulon scoparium was collected from sites listed in Table 1. Clones were propagated from vegetative apices, as no fertile material was seen in any collection. All isolates were incubated in a range of temperature conditions to determine rates of growth and long-term survival capacity. Incubations were done in growth cabinets $\left( \pm 1-2^{\circ} \mathrm{C}\right)$ or

Table 1. Collection sites of isolates of Stypocaulon scoparium

\begin{tabular}{|lll|}
\hline Isolate & Location & Collector \\
\hline CAN1 & Bonne Bay, Nfld., Canada $\left(49^{\circ} \mathrm{N}, 58^{\circ} \mathrm{W}\right)$ & E. Henry \\
CAN2 & Rustico, P. E. I., Canada $\left(46^{\circ} \mathrm{N}, 63^{\circ} \mathrm{W}\right)$ & J. McLachlan \\
CAN3 & Rustico, P. E. I., Canada & J. McLachlan \\
CAN4 & Rustico, P. E. I., Canada $\left(46^{\circ} \mathrm{N}, 63^{\circ} \mathrm{W}\right)$ & I. Novaczek \\
EUR1 & Roscoff, Brittany, France $\left(48^{\circ} \mathrm{N}, 4^{\circ} \mathrm{W}\right)$ & I. Novaczek \\
EUR2 & Calvi, Corsica, France $\left(42^{\circ} \mathrm{N}, 8^{\circ} \mathrm{E}\right)$ & I. Novaczek \\
EUR3 & Calvi, Corsica, France & I. Novaczek \\
EUR4 & Canary Islands $\left(28^{\circ} \mathrm{N}, 15^{\circ} \mathrm{W}\right)$ & E. Henry \\
\hline
\end{tabular}


water baths $\left( \pm 0.5^{\circ} \mathrm{C}\right)$, under cool-white fluorescent light. For all cultures, sterile PES medium (McLachlan, 1973) based on North Sea water of $33 \%$ salinity, was used.

Isolates were maintained in stock culture at $10^{\circ} \mathrm{C}$, long days $(16 \mathrm{~h}$ light, $8 \mathrm{~h}$ dark). In preparation for experiments, plants were moved from stock culture toward the desired experimental temperature at a rate of no more than $5^{\circ} \mathrm{C} \mathrm{wk}^{-1}$ and then acclimated to the experimental temperature for at least 5 days. All material to be tested at a particular light and temperature condition received the same acclimation and all available isolates were tested concurrently.

For growth studies, 5 apices, each about $3 \mathrm{~mm}$ long, were dissected from each isolate. Each apex was placed in a $50 \mathrm{~mm}$ diameter, sterile plastic Petri dish $3 / 4$ full of medium and sealed with parafilm to prevent evaporation. The length of each apex was drawn at a standard magnification $(7 \times)$ using a dissecting microscope fitted with a camera lucida. The culture dishes did not have to be opened, and the process was performed quickly to minimise temperature fluctuations. The drawings were later measured ( $\pm 1 \mathrm{~mm}$ ) using a Hewlett Packard digitiser (model 9835A). Drawings were made at intervals of 2 to 10 days, depending upon the rate of growth. Measurements were continued until a straight line could be fitted through at least three consecutive datum points plotted on semilog paper, indicating a steady, logarithmic rate of elongation. Where no growth was apparent, measurements were discontinued after 4 weeks or when the material was obviously dead. Apices damaged by transfer to a sublethal temperature were allowed to regenerate before measurements were begun. Quantum flux densities of 10 and/or $40 \mu \mathrm{mol} \mathrm{m}^{-2} \mathrm{~s}^{-1}$ were used at each temperature. All trials were conducted in long days, except at $-2{ }^{\circ} \mathrm{C}$, where short $(8 \mathrm{~h}$ light, $16 \mathrm{~h}$ dark) days were employed. In general, experiments at sublethal high and low temperatures were performed at $10 \mu \mathrm{mol} \mathrm{m}^{-2} \mathrm{~s}^{-1}$, to minimise damage (Cambridge et al., 1984; Yarish et al., 1984, 1986).

Relative growth rate (RG) of each apex, expressed as $\%$ increase day ${ }^{-1}$, was computed for the period of exponential growth, as follows:

$$
\mathrm{RG}=100(\ln \mathrm{L} 2-\ln \mathrm{L} 1) /(\mathrm{T} 2-\mathrm{T} 1) \quad(\text { Kain, 1987) }
$$

where L2 = final length, L1 = initial length, T2 = final time (d) and T1 = initial time. Five replicates were averaged to give the mean growth rate for each isolate. Differences among isolates were tested by a posteriori Student-Newman-Keuls (SNK) and Scheffe multiple range tests, using the Statistical Package for Social Sciences (SPSS).

To determine lethal limits, whole plants were incubated in $500 \mathrm{ml}$ flasks at extreme temperatures for a period of 3 months. This relatively long incubation time was used in order to gain results relevant to survival over a summer or winter period in the field. Temperatures of $-2,0,5,20,22,25,27,30,33$ and $35^{\circ} \mathrm{C}$ were tested, in long and/or short daylengths. Because high quantum flux densities appeared to hasten death at extreme temperatures, all tests were conducted at about $10 \mu \mathrm{mol} \mathrm{m}^{-2} \mathrm{~s}^{-1}$. Trials at $0^{\circ} \mathrm{C}$ were also performed in darkness. The medium was changed at 2-3-week intervals, using medium previously warmed or cooled to the appropriate temperature to avoid thermal shock. After 3 months, the cultures were transferred to 15 or $20^{\circ} \mathrm{C}$, long days and observed for 1 month or until obvious growth had occurred. When test cultures appeared to be dead or dying in less than 3 months, portions were removed to test for recovery. All tolerance tests were performed on at least 2 separate occasions. 


\section{RESULTS}

Isolates of Stypocaulon scoparium from Canada differed markedly from European isolates both in their lethal limits (Table 2) and in their ability to grow over the range of temperatures tested (Figs 1-8). Whereas apices from plants from the western Atlantic not only survived but grew at 0 and $-2{ }^{\circ} \mathrm{C}$ (Figs 1-4), these temperatures were lethal for apices of European isolates (Figs 5-8). In no instance did the Canadian isolates appear

Table 2. Thermal tolerance of isolates of Stypocaulon scoparium (whole plants) in culture. $++=$ undamaged $+=$ alive but damaged; $+-=$ dead or damaged; $-=$ dead; nd $=$ no data. Incubation time 3 months. $S=$ short days; $L=$ long days; $D=$ dark

\begin{tabular}{|c|c|c|c|c|c|c|c|c|c|c|c|c|c|c|c|}
\hline \multirow[t]{2}{*}{ Isolate } & \multicolumn{15}{|c|}{ Temperature $\left({ }^{\circ} \mathrm{C}\right)$ and Daylength } \\
\hline & $-2 S$ & OS & $\mathrm{OL}$ & OD & $5 \mathrm{~S}$ & $5 \mathrm{~L}$ & $20 \mathrm{~S}$ & $20 \mathrm{~L}$ & $22 \mathrm{~L}$ & $25 S$ & $25 \mathrm{~L}$ & $27 \mathrm{~L}$ & $30 \mathrm{~L}$ & $33 \mathrm{~L}$ & $35 \mathrm{~L}$ \\
\hline CAN1 & ++ & nd & ++ & nd & ++ & ++ & nd & +- & +- & nd & - & - & - & & \\
\hline CAN2 & ++ & nd & ++ & nd & ++ & ++ & nd & +- & - & nd & - & - & - & & \\
\hline CAN3 & ++ & nd & ++ & nd & ++ & ++ & nd & + & +- & nd & - & - & - & & \\
\hline CAN4 & ++ & ++ & ++ & ++ & ++ & ++ & $+t$ & + & - & - & - & - & - & & \\
\hline EUR1 & - & - & +- & ++ & ++ & + & ++ & ++ & ++ & ++ & ++ & ++ & + & - & - \\
\hline EUR2 & - & nd & - & nd & +- & - & ++ & ++ & ++ & ++ & $+t$ & ++ & +- & - & - \\
\hline EUR3 & - & nd & +- & nd & +- & + & ++ & ++ & $+t$ & ++ & $+t$ & ++ & +- & - & nd \\
\hline EUR4 & - & nd & - & nd & + & + & ++ & ++ & ++ & ++ & $+t$ & ++ & + & - & nd \\
\hline
\end{tabular}

damaged after transfer to low temperatures. Whole plants of European isolates suffered damaged apices or died when transferred to 5 or $0^{\circ} \mathrm{C}$ and all died at $-2^{\circ} \mathrm{C}$. Results at 0 and $5^{\circ} \mathrm{C}$ varied depending on the combination of isolate and daylength (Table 2). EUR1, the northernmost isolate, survived $0^{\circ} \mathrm{C}$ only after acclimation for a month at $5{ }^{\circ} \mathrm{C}$, sustaining less damage at this temperature when in darkness. No amount of acclimation allowed long-term survival of the more southerly isolates at $0^{\circ} \mathrm{C}$.

Over the range of 5 to $15^{\circ} \mathrm{C}$, growth rates of the European isolates were not, as a group, significantly different from those of the Canadian isolates. However, at $5^{\circ} \mathrm{C}$, two Canadian isolates grew significantly faster $(p<0.05)$ than the European isolates. All European isolates grew at rates significantly higher than all Canadian isolates $(p<0.05)$ at temperatures of $20^{\circ} \mathrm{C}$ or more. The maximum growth rates of European plants were consistently higher than those of Canadian isolates.

The differences in upper lethal limits and in growth at high, sublethal temperatures were dramatic (Table 2; Figs 1-8). Apices of Canadian isolates grew at 20 and $22^{\circ} \mathrm{C}$, but always at a slower rate than at 10 or $15^{\circ} \mathrm{C}$ (Figs 1-4). When incubated for a long period at $20^{\circ} \mathrm{C}$, whole plants were damaged and appeared unhealthy. At $22^{\circ} \mathrm{C}$ all the Canadian isolates died or were severely damaged after 3 months. At $25^{\circ} \mathrm{C}$ all died completely after 1 month (Table 2). In contrast, the European isolates all had a broad range of optimal growth temperature from 10 to 27 or $30^{\circ} \mathrm{C}$ (Figs $5-8$ ). Growth rate was most markedly reduced at $30^{\circ} \mathrm{C}$ in the isolate from Brittany (EUR1, Fig. 5), whereas the Canary Islands isolate grew well at this temperature (EUR4, Fig. 8). All four isolates were damaged by long-term incubation at $30^{\circ} \mathrm{C}$ but were able to regenerate after 3 months at this 
temperature. They were all killed by prolonged exposure to $33^{\circ} \mathrm{C}$ but even at this extreme temperature the Canary Islands clone (EUR4, Fig. 8) was able to grow well for a number of weeks before showing signs of damage, and grew at a rate significantly higher $(p<0.05)$ than that of other isolates.

\section{DISCUSSION}

Culture experiments have shown that the apparent anomalies in the limits of geographic distribution of Stypocaulon scoparium in the North Atlantic Ocean are owing to the very different thermal tolerances of plants on the eastern and western sides of the ocean. European isolates resemble warm-temperate to tropical species (Cambridge et al., 1987). They do not tolerate sub-zero temperatures and suffer damage or die even at $5^{\circ} \mathrm{C}$, but grow well above $25^{\circ} \mathrm{C}$ and sustain damage only at $30^{\circ} \mathrm{C}$. One would expect such plants to occur in the tropics, making the Nigerian record entirely believable. In contrast, Canadian isolates resemble Arctic to cold-temperate species such as Devaleraea ramentacea (L.) Guiry and Phycodrys rubens (L.) Batt. (Novaczek \& Breeman, unpubl. obs.) in that they tolerate $-2{ }^{\circ} \mathrm{C}$ and even grow at this temperature, while being unable to tolerate or grow at temperatures much above $20^{\circ} \mathrm{C}$. The southern boundary of Stypocaulon in the western Atlantic coincides with the $18^{\circ} \mathrm{C}$ summer isotherm, making this boundary defined by an upper lethal limit.

Among the European isolates there was evidence of ecotypic variation. The northernmost isolate, EUR1, was least able to grow at high temperatures while the southernmost isolate, EUR4, grew better than all others at 30 and $33^{\circ} \mathrm{C}$. A relative disadvantage at low temperatures accompanied the better high temperature tolerance. Whereas EUR4 died completely at $0^{\circ} \mathrm{C}$ and was severely damaged at $5^{\circ} \mathrm{C}$, EUR1 was undamaged or able to regenerate from surviving cortical cells after exposure to these low temperatures (Table 2). There were no differences in tolerance among the Canadian isolates (Table 2) nor were there distinct differences among short-term growth rates at either end of the temperature scale.

In general, thermal ecotypes that have different absolute survival limits appear to be rare in morphologically well-defined species of marine algae (Novaczek \& Breeman, unpubl. obs.; Bolton \& Luning, 1982; Guiry et al., 1987; Breeman, 1988), even in cases where there are variations in the thermal response with respect to reproduction (Novaczek, 1984), morphogenesis (tom Dieck, 1987; Rietema \& van den Hoek, 1984) or growth (see refs. in Breeman, 1988). When they do occur, variations in upper lethal limits are only of $1-3^{\circ} \mathrm{C}$ (Novaczek \& Breeman, unpubl. obs.; Lüning et al., 1987; Breeman, 1988; Gerard \& DuBois, 1988). One apparent anomaly is the case of the cosmopolitan "species" Ectocarpus siliculosus (Dillw.) Lyngb. (Bolton, 1983). This taxon probably encompasses a number of species, as there are both morphological differences and degrees of intersterility among the isolates tested (Müller, 1976, 1979). Similarly, differences have been documented between eastern and western Atlantic isolates of Callithamnion tetragonum (Withering) S.F.Gray (Whittick \& West, 1979; Yarish et al., 1986), but taxonomic controversy suggests that more than one species is involved. Short-term photosynthetic measurements at extreme temperatures have shown differences between plants that have had different histories of acclimatization (Mathieson \& Norall, 1976) but these do not indicate genetic variation, nor can the results be extrapolated to predict long-term growth 
and survival in the field at extreme temperatures. Longer term experiments have also indicated differences in thermal tolerance of about $2^{\circ} \mathrm{C}$ that are attributable to seasonal acclimatization (Lüning, 1984) but again these do not indicate the genetic difference required for the recognition of an ecotype. It has been documented that in some species, short-term exposure to lethal temperature may result in faster average growth rather than in mortality (Stromgren, 1977, 1983). When attempting to test the genetic component of thermal tolerance, therefore, acclimation procedures must be thorough and standardized.

Slight differences in thermal response have been found between haploid and diploid phases of some monomorphic species (Novaczek et al., 1987; Yarish et al., 1986), and also
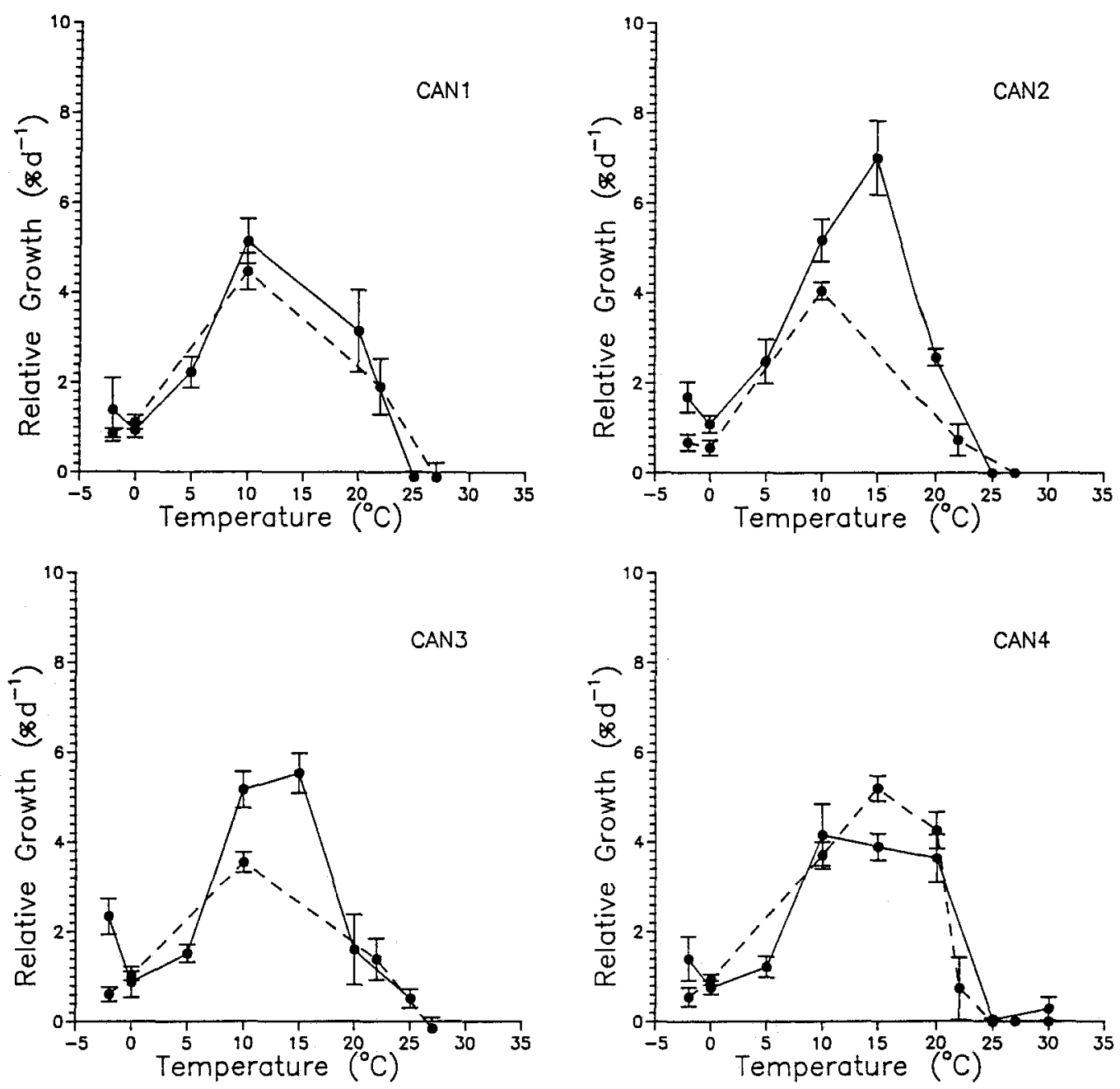

Figs 1-4. Relative growth rates (mean \pm standard error) of all isolates (see Table 2) of Stypocaulon scoparium at different temperatures. Solid line = quantum flux density $40 \mu \mathrm{mol} \mathrm{m} \mathrm{m}^{-2} \mathrm{~s}^{-1}$; broken line $=10 \mu \mathrm{mol} \mathrm{m} \mathrm{m}^{-2} \mathrm{~s}^{-1}$. Fig. 1. Isolate CAN1; Fig. 2. Isolate CAN2; Fig. 3. Isolate CAN3; Fig. 4. Isolate 
between plants at different morphogenetic stages (Lüning, 1984). In these cases the various plants either tolerated a lethal temperature for different lengths of time or, if there was a difference in lethal limits, it was of only a few degrees. The only large differences (over $5^{\circ} \mathrm{C}$ ) in thermal tolerance that have been recorded are those between micro- and macrothallic phases of heteromorphic brown algae (Novaczek et al., 1986; Novaczek, 1987).

It seems that, for any particular morphological phase of an algal species, thermal tolerance is a highly conservative genetic feature. Indeed, some modern methods of estimating phanerozoic ocean temperatures depend upon the assumption that fossil phytoplankton had the same range of thermal tolerance as morphologically identical
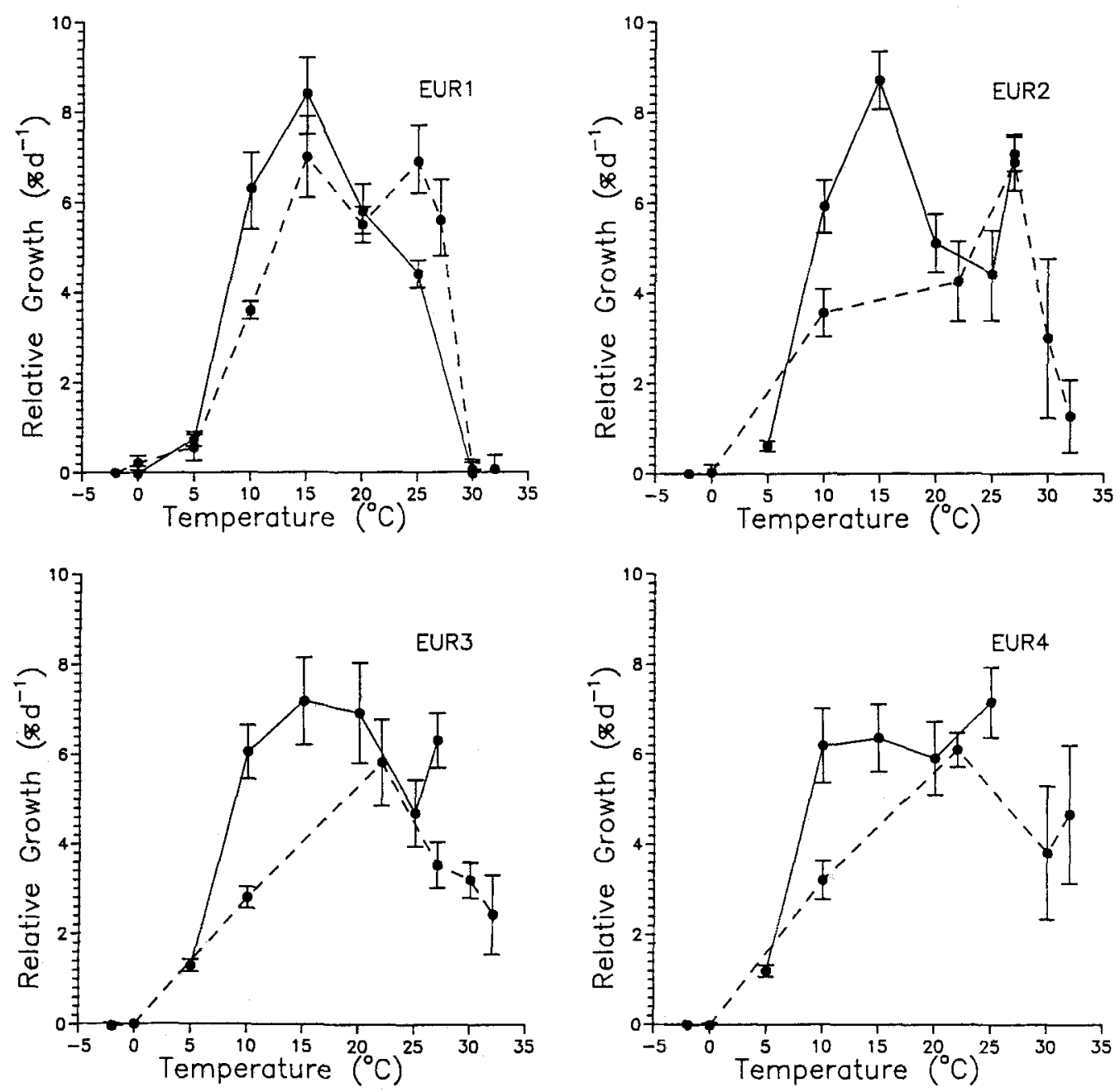

Figs 5-8. Relative growth rates (mean \pm standard error) of all isolates (see Table 2) of Stypocaulon scoparium at different temperatures. Solid line $=$ quantum flux density $40 \mu \mathrm{mol} \mathrm{m} \mathrm{m}^{-2} \mathrm{~s}^{-1}$; broken line $=10 \mu \mathrm{mol} \mathrm{m} \mathrm{m}^{-2} \mathrm{~s}^{-1}$. Fig. 5. Isolate EUR1; Fig. 6. Isolate EUR2; Fig. 7. Isolate EUR3; Fig. 8. Isolate EUR4 
extant species. In general, the conclusions drawn from studies based on this assumption have been supported by conclusions drawn by other means (Lamb, 1977). The few exceptions to this are of interest, as they indicate that there may be a link between shifts in low temperature tolerance and potentially mutagenic events such as the reversal of the earth's magnetic field (Kennett, 1968, 1970).

In the case of Dictyota dichotoma (Huds.) Lamour., where a large difference in thermal tolerance had been noted between eastern and western Atlantic populations (Biebl, 1962), recent research has shown that the plants of the North American coast are a different species from those of the European coast (Schnetter et al., 1987). In the case of Stypocaulon scoparium, the large differences in thermal tolerance indicate that in this case, too, the plants on the eastern and western sides of the Atlantic are of two separate entities.

Stypocaulon scoparium is not limited to the Atlantic Ocean but is also recorded in the northwest Pacific and in the Caspian Sea. Its occurrence in the Caspian Sea indicates that the European populations are probably descended from an ancient species that entered the developing North Atlantic Ocean from the warm, equatorial Tethys Sea. The Caspian Sea was once an arm of the Tethys. A Tethyan origin is consistent with the present-day thermal tolerance of the European plants, which places them in the group of warmtemperate to tropical species.

Patterns of variation in thermal response may provide clues to evolutionary history. Species of Tethyan origin will have been in the Atlantic since it was first formed over 150 million years ago. Ecotypic variation, resulting from evolution in the face of changing temperature regimes, may be more evident in Tethyan algae than in species more recently introduced to the ocean. For instance, southern Atlantic and presumably Tethyan populations of Ectocarpus siliculosus encompass many ecotypes and probably several species having distinctive thermal responses. In contrast, Laminaria saccharina, which is thought to be a more recent introduction from the north, has developed thermal ecotypes only at the southernmost boundary of distribution, where populations experience the most extreme selective pressure from high summer temperatures (Bolton \& Lüning, 1982; Gerard \& DuBois, 1988). In this study we found that the European, presumably Tethyan, species of Stypocaulon did encompass populations having different abilities to grow and survive at both extreme high and extreme low temperatures.

In the Pacific, Stypocaulon scoparium is recorded from the shores of northern Japan and the Sakhalin Peninsula of the USSR. When grown in culture, plants from Japan resemble the Canadian Stypocaulon in that they produce a basal disc (H. Kawai, pers. comm.). In contrast, European plants are only known to be attached by rhizoids (Prud'homme van Reine, pers. comm.; Novaczek, unpubl. obs.). The southern limit of distribution of Pacific Stypocaulon lies near the $18^{\circ} \mathrm{C}$ summer isotherm, suggesting that in physiological terms, also, these plants are closer to Canadian populations than to European ones. A second, poorly known species, Halopteris dura Rupr., which closely resembles S. scoparium (Ruprecht, 1851), has been recorded in far northern Pacific waters, overlapping in distribution with $S$. scoparium and extending north into the Bering Sea. Tokida (1931) considers $H$. dura to be conspecific with $S$. scoparium. Unfortunately, the type specimen lacks a holdfast (Prud'homme van Reine, pers. comm.) and the written descriptions of this northern entity (Ruprecht, 1851; Perestenko, 1980) do not indicate definitively whether it is closely allied to the species found in Canada. 
The Canadian species, with its cold-temperature to Arctic type of thermal response, may have evolved from the Tethyan stock in response to cooling temperatures. On the other hand, the existence of one or two sister species in the northwestern Pacific suggests that the ancestors of Canadian populations entered the Atlantic from the north. The ancestral stock may have been part of the flora of the present-day Arctic basin at the time when it became separated from the Pacific Ocean by the Bering land bridge. The species could then have entered the north Atlantic about 55 or 40 million years ago when the rifting process that formed the Atlantic Ocean severed Greenland from Norway, allowing Arctic water to flow in (Lüning, 1985). Alternatively, the ancestral stock may have invaded more recently from the north Pacific following the opening of the Bering land bridge, which once again allowed the confluence of Pacific and Arctic waters, in the late Pliocene (McKenna, 1983). The present-day absence of the species from the Arctic indicates that if the plants migrated through these northern waters, they must have done so prior to the deterioration of polar temperatures during the ice ages.

Considering the possible introduction of the Canadian species from the north, and its present ability to tolerate sub-zero temperatures, it is then surprising that populations are not found farther north than southern Labrador on the Canadian coast. Summer temperatures in embayments north of this point can approach $10^{\circ} \mathrm{C}$, which is more than adequate for vigorous growth. Even the European plants might be expected to grow farther north along the coast of Norway, as they tolerate more severe winters in the Baltic than on the coast, and also can grow at the summer temperatures of this coast (roughly $10^{\circ} \mathrm{C}$ ). However, even for the hardiest thermal ecotype, winters in which the temperature drops below $5^{\circ} \mathrm{C}$ for more than 3 months would be very stressful if not fatal. The length of winter, rather than any particular low lethal temperature, may therefore determine the northern geographic boundary in Europe. It is possible that competition from other algae or herbivory play a part, but these factors have never been shown to control large-scale distribution (Breeman, 1988). Alternatively, the northern boundaries of both eastern and western Atlantic populations may be explained by a requirement for some particular condition for reproduction which is not met under current northern climatic regimes. This might be a need for high summer temperatures or for some particular temperaturedaylength combination. The requirements for reproduction in Stypocaulon are enigmatic, as the plant has never reproduced in culture (Novaczek, pers. obs.; Henry, pers. comm.) and no detailed field observations have been published. From present northern boundaries, a requirement for a minimum of $10^{\circ} \mathrm{C}$ is suggested for Canadian plants, and of $14^{\circ} \mathrm{C}$ for European plants. However, other thermal requirements may prevail if the plants have a daylength response.

Before a choice can be made from the various possible phylogenetic relationships among the disjunct populations currently included in Stypocaulon scoparium, more information is required. Knowledge of the thermal responses of the Pacific taxa and a more thorough understanding of their morphological variation are needed. Modern methods of genetic analysis could also be employed to determine how closely related each taxon is to the others.

Acknowledgements. The senior author was supported in this work by the Netherlands Organisation for the Advancement of Pure Research (ZWO). We wish to thank Dr E. Henry for kindly sharing his cultures with us, Dr J. McLachlan and W. Kooistra for collecting some isolates, and the staff of the University of Liège Marine Laboratory at Calvi, France, for their cooperation. 


\section{LITERATURE . CITED}

Audiffred, P. A. J., 1985. Marine algae of El Hierro (Canary Islands). - Vieraea 14, 157-183.

Biebl, R., 1962. Temperaturresistenz tropischer Meeresalgen. (Verglichen mit jener von Algen in temperierten Meeresgebieten) - Botanica mar. 4, 241-254.

Bolton, J. J., 1983. Ecoclinal variation in Ectocarpus siliculosus (Phaeophyceae) with respect to temperature growth optima and survival limits. - Mar. Biol. 73, 131-138.

Bolton, J. J. \& Lüning, K., 1982. Optimal growth and maximal survival temperatures of Atlantic Laminaria species (Phaeophyta) in culture. - Mar. Biol. 66, 89-94.

Breeman, A. M., 1988. Relative importance of temperature and other factors in determining geographic boundaries of seaweeds: experimental and phenological evidence. - Helgoländer Meeresunters. 42, 199-241.

Cambridge, M., Breeman, A. M., Oosterwijk, R. van \& Hoek, C. van den, 1984. Temperature responses of some North Atlantic Cladophora species (Chlorophyceae) in relation to their geographic distribution. - Helgoländer Meeresunters. 38, 349-363.

Cambridge, M. L., Breeman, A. M., Kraak, S. \& Hoek, C. van den, 1987. Temperature responses of tropical to warm temperate Cladophora species in relation to their distribution in the North Atlantic Ocean. - Helgoländer Meeresunters. 41, 329-354.

Christensen, T., Kock, C. \& Thomsen, H. A., 1985. Distribution of algae in Danish salt and brackish waters. Inst. Sporeplanter, Copenhagen, $64 \mathrm{pp}$.

Dieck, I. tom, 1987. Temperature tolerance and daylength effects in isolates of Scytosiphon lomentaria (Phaeophyceae) of the North Atlantic and North Pacific Ocean. - Helgoländer Meeresunters. $41,307-321$.

Gerard, V. A. \& DuBois, K. R., 1988. Temperature ecotypes near the southern boundary of the kelp Laminaria saccharina. - Mar. Biol. 97, 575-580.

Guiry, M. D., Tripoldi, G. \& Lüning, K., 1987. Biosystematics, genetics and upper temperature tolerance in Gigartina teedii (Rhodophyta) from the Atlantic and Mediterranean. - Helgoländer Meeresunters. 41, 283-295.

Hoek, C. van den, 1982a. The distribution of benthic marine algae in relation to the temperature regulation of their life histories. - Biol. J. Linn. Soc. Lond. 18, 81-144.

Hoek, C. van den, 1982b. Phytogeographic distribution groups of benthic marine algae in the North Atlantic Ocean. A review of experimental evidence from life history studies. - Helgoländer Meeresunters. 35, 153-214.

Kain, J. M., 1987. Photoperiod and temperature as triggers in the seasonality of Delesseria sanguinea. - Helgoländer Meeresunters. 41, 355-370.

Kennett, J. P., 1968. Globerotalia truncatulinoides as a paleo-oceanographic index. - Science, N.Y. $159,1461-1463$.

Kennett, J. P., 1970. Pleistocene paleoclimates and foraminiferal biostratigraphy in sub-Antarctic deep-sea cores. - Deep Sea Res. 17, 125-140.

Kjellman, F. R., 1883. The algae of the Arctic sea. - K. svenska Vetensk-Akad. Handl. 20 (5), 1-350.

Lamb, H. H., 1977. Climate: Present, past and future. Methuen, London, 2, 1-835.

Lawson, G. M. \& John, D. M., 1982. The marine algae and coastal environment of tropical west Africa. Cramer, Vaduz, $455 \mathrm{pp}$.

Lüning, K., 1984. Temperature tolerance and biogeography of seaweeds: the marine algal flora of Helgoland (North Sea) as an example. - Helgoländer Meeresunters. 38, 305-317.

Lüning, K., 1985. Meeresbotanik. Thieme, Stuttgart, $375 \mathrm{pp}$.

Lüning, K., Guiry, M. D. \& Masuda, M., 1987. Upper temperature tolerance of North Atlantic and North Pacific geographical isolates of Chondrus species (Rhodophyta). - Helgoländer Meeresunters. $41,297-306$.

Maggs, C. A., 1986. Scottish marine macro-algae: a distributional checklist, biogeographical analysis and literature abstract. - Rep. Nat. Cons. Counc., Petersborough. 635, 1-137.

Mathieson, A. C. \& Norall, T. L., 1976. Physiological studies of subtidal red algae. - J. exp. mar. Biol. Ecol. 20, 237-247.

McKenna, M. C., 1983. Cenozoic paleogeography of North Atlantic land bridges. In: Structure and development of the Greenland Scotland ridge, new methods and concepts. Ed. by M. H. P. Bott, S. Saxon, M. Talwani \& J. Thiede. Plenum Press, New York, 351-399. 
McLachlan, J., 1973. Growth media - marine. In: Handbook of phycological methods: Culture methods and growth measurements. Ed. by J. R. Stein. Cambridge Univ. Press, Cambridge, 25-51.

Menez, E. G. \& Mathieson, A. C., 1981. The marine algae of Tunisia. - Smithson. Contr. mar. Sci. 10, $1-59$.

Müller, D., 1976. Sexual isolation between a European and American population of Ectocarpus siliculosus. - J. Phycol. 12, 252-254.

Müller, D., 1979. Genetic affinity of Ectocarpus siliculosus (Dillw.) Lyngb. from the Mediterranean, North Atlantic and Australia, - Phycologia 18, 312-318.

Novaczek, I, 1984. Response of gametophytes of Ecklonia radiata (Laminariales) to temperature in saturating light. - Mar. Biol. 82, 241-245.

Novaczek, I., Bird, C. J. \& McLachlan, J., 1986. Temperature response of Chorda filum and C. tomentosa (Laminariales) from Nova Scotia. - Can. J. Bot. 64, 2414-2420.

Novaczek, I., Bird, C. J. \& McLachlan, J., 1987. Phenology and temperature tolerance of the red algae Dasya baillouviana, Chondria baileyana, Griffithsia globulifera and Lomentaria baileyana (Rhodophyceae) in Nova Scotia. - Can. J. Bot. 65, 57-62.

Novaczek, I., 1987. Periodicity of epiphytes on Zostera marina in two embayments of the southern Gulf of St. Lawrence. - Can. J. Bot. 65, 1676-1681.

Perestenko, L. P., 1980. Vodorosli Zaliva Petra Velikogo. "Nauka", Leningrad, 232 pp.

Rietema, H. \& Hoek, C. van den, 1984. Search for possible latitudinal ecotypes in Dumontia contorta (Rhodophyta). - Helgoländer Meeresunters. 38, 389-399.

Rueness, J., 1977. Norsk algeflora. Universitets forlaget, Oslo, $266 \mathrm{pp}$.

Ruprecht, F. J., 1851. Phycologia Ochotiensis. In: Middendorff's Sibirische Reise. Repr. Cramer, Vaduz, 1 (2), 1-435. (Bibliotheca Phycologica. Bd 39.)

Schnetter, R., Hornig, I. \& Weber-Peukert, G., 1987. Taxonomy of some North Atlantic Dictyota species (Phaeophyta), - Hydrobiologia 151-152, 193-197.

South, G. R. \& Tittley, I., 1986. A checklist and distributional index of the benthic marine algae of the North Atlantic Ocean. British Museum (Natural History), London, $76 \mathrm{pp}$.

Stromgren, T., 1977. Short-term effects of temperature upon growth of intertidal Fucales. - J. exp. mar. Biol. Ecol. 29, 181-195.

Stromgren, T., 1983. Temperature-length growth strategies in the littoral alga Ascophyllum nodosum (L.) Le Jol. - Limnol. Oceanogr. 28, 515-521.

Tokida, J., 1931. On two species of Sphacelariales new to Japan, - Transact. Sapporo nat. Hist. Soc. $11,215-220$.

Waern, M., 1952. Rocky-shore algae in the Oregrund archipelago. - Acta phytogeogr. suec. 30, $1-298$.

Whittick, A. \& West, J. A., 1979. The life history of a monoecious species of Callithamnion (Rhodophyta, Ceramiaceae) in culture. - Phycologia 18, 30-37.

Yarish, C., Breeman, A. M. \& Hoek, C. van den, 1984. Temperature, light and photoperiod responses of some northeast American and west European endemic rhodophytes in relation to their geographic distribution. - Helgoländer Meeresunters. 38, 273-304.

Yarish, C., Breeman, A. M. \& Hoek, C. van den, 1986. Survival strategies and temperature responses of seaweeds belonging to different biogeographic distribution groups. - Botanica mar. 29, 215-230.

Zinova, A. D., 1967. Opredelitel' zelenych, burych i krasnych vodoroslej juznych morej SSSR. "Nauka", Leningrad, $398 \mathrm{pp}$. 